https://doi.org/10.18485/ccs_cs.2022.19.19.10

\author{
Михаило Стојановић \\ Иновачиони центар Универзитета у Нишу \\ e-mail: mihailophilosophy@gmail.com
}

\title{
ПОЈАМ ДУШЕ У АНТИЦИ
}

Апстракт: У античкој филозофији се појмови душа, унутрашњост и свест у свом интендираном значењу налазе као веома блиски. Појам чүұй представља крајње полисемичну одреднииу која унутар себе садржава читав низ суптилних значењских карактеристика које као да се окрећу око јединственог иентра. Постоји читав низ мислилаца у антиции који су на душу т.j. унутрашњост гледали као на математичко суштаство. Ових суштастава има неколико по врстама, а оне се поглавито разграничавају складно захватању геометријском, аритметичком или хармонијском методом.

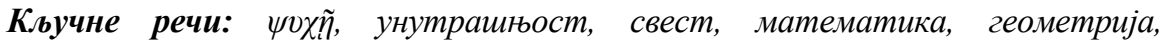
аритметика, хармонија.

\section{Два појма душе}

Упитан да ли верује да постоји душа, човек некада одговара “да”, а некада “не”. Чини се доследним приклонити се ма којој страни (неретко се каже, ни за једно ни за друго се не могу пружити какви докази), предма се мни, а из куртоазије спрам штовања туђе слободе нешто ређе говори да је истина ипак на страни одрицања. Ова вековна пракса изродила је нешто што се може обележити као мистичан појам душе. Појам треба да одговара одговору на питање о природи тог мистичног бића које одбацујемо или себи приписујемо; душа као нешто неухватљиво, невидљиво и неосетно; предео који се не може доказати чак ни онда када се реч “доказ” не узима у једном стриктном, ригидном смислу, већ онако како се то мисли када се за доказ сопствене будности узима самоизвесност тога стања. Зачуђујуће је откриће са којим се сусрећемо када корене овог виђења пратимо у прошлост. Концепција која читаве генерације одвраћа од контемплације метафизичких темата, не само што је релативна новост, макар у погледу опште распрострањености у слагању, већ је и продукт материјалистичке представе света. Тако се душа скрила, повукла иза завеса појмовног мишљења и умног зрења те прелетела у предео недохватљивог. Но највећи број спекулативних мислилаца идеалистичког настројења, почевши од питагорејског друштва, Академије и Ликеја, преко неоплатоничара и перипатетичара, па све до позног времена патристике и зоре схоласитичара, овај мистичан појам душе не би допустио.

Овиме се долази до другог, стварног појма душе. За све мислиоце оваквог настојења, а ово се тврди без изузетка, душа је нешто постојеће, понекад у већој мери него када су питању ствари спољашњег искуства. Када се каже да је нешто постојеће, тиме се 
сасвим ретко мисли на какав ентитет, нешто што се поседује ${ }^{1}$, као што је то ствар са једним органом; душа је од овога ближа појму постојања. У Tuмajy² је Платон одређује као топос, место, простор, предео обитавања идеја. Ово виђење неизбежно човекову мисао води у разумевање метафизичких темата. У античкој филозофији се појмови душа, унутрашњост и свест у свом интендираном значењу налазе као веома блиски. У наставку треба размотрити даље одреднице и партикуларне проблеме који су се јављали поводом природе душевности.

\section{Контекстуално - семантичка иститивања}

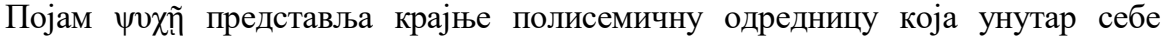
садржава читав низ суптилних значењских карактеристика које као да се окрећу око јединственог центра. Не би ли се овоме центру приближило, али исто тако, не би ли се распознао варијетет одређујућих разлика, у наставку прилажемо кратак преглед варијантних контекстних форми у којима се $\psi$ ұп̃ јављала.

Избор је претежно одређен Хомером. Уколико се различита значења покажу овде, у извору Грчке писмености, онда не треба сумњати да су у потоњим вековима она

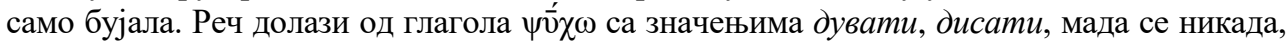
чак ни у Хомеровим списима није на тај начин употребљавала. Идеја дисања као даха живота стоји у ноетичкој основи овога појма.

У првом смислу чvхп̃ значи принцип живота, животињско тело, élan vital, душу и живот:

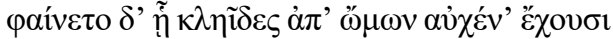

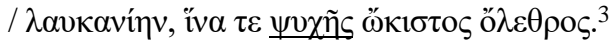

Само се видело грло, где управо врат од рамена, кључне раздвајају кости, где најбржа смрт је животу.

У раној грчкој философији, када се истанчана терминологија још увек ствара,

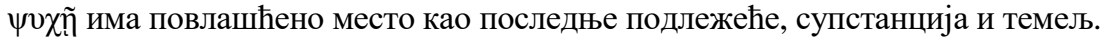

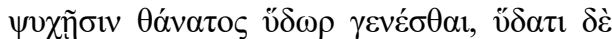

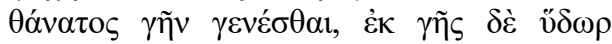

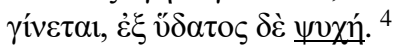

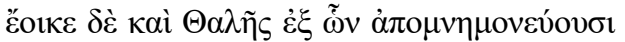

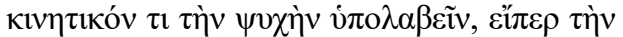

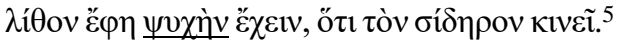

Јер смрт је душама постати водом, и смрт води постати земљом. Али вода долази од земље, а од воде, душа.

Талес, такође, према ономе што је забележено, изгледа да предпоставља да је животни принцип нешто покретајуће,

1 Било је, наравно, и таквих становишта, мада се онда реч “поседовати” узимала у једном слободнијем и онтолошки мање везивајућем смислу. Од ових се највише истичу Порфирије Еустрације (митрополит ницејски и номиналист), Аспазије (филолог из другог века) и Михаило Ефешки (надбискуп ефешки, коментатор Аристотела). Ову су теорију, разрешавајући неке терминолошке незгоде до њеног пуног смисла извели арапски философи Авицена, Авероес и Абубацер; наиме, оно што је код Грка било одређено као “поседовано”, Арапи су (држим) исправно разумели као “стечено”. Види: Kurdzialek, 1971, 35-75.

2 Platon, 1981.

3 Homer 2015, 22.324.

4 Heraklit 1981, фp. 36.

5 Аристотел 2001, 405a20. 
јер је рекао да магнет мора имати овај принцип живота јер даје покрет гвожђу.

У другом смислу, чvұп̃ није само подлежеће телу, принцип живота, већ и оно што се од тела разликује а што поглавито држимо за вредно, $ү ү и \tilde{~ с е ~ с а д а ~ с х в а т а ~ к а о ~ д у ш а ~}$ и дух, начело сопствености.

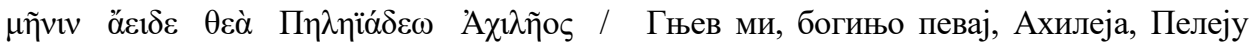

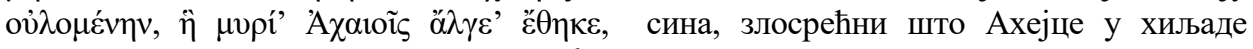

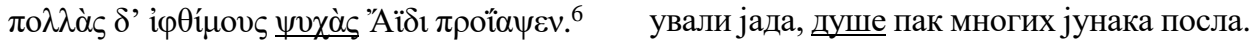

Овде $\psi v \chi \tilde{n ̃ ~ в е ћ ~ в и ш е ~ н и ј е ~ н е ш т о ~ б е з л и ч н о, ~ п р и н ц и п ~ к о ј и ~ с а м о ~ п о с р е д н о ~ с е ж е ~ д о ~}$ људских живота. Она јесте људски живот, и то његов бесмртни део. Крајња воља за бесмртношћу, што је Ахилеју непрестано стајала пред очима, није била жеља за бесмртношћу тела јер је оно, поредећи се са $\psi v \chi \tilde{\eta}$, нешто последње и унижено. Две реченице откриће додатне карактеристике:

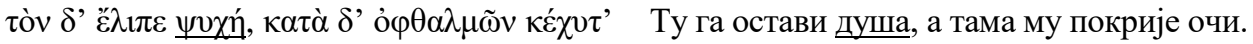

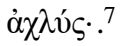

Како реченица која након ове следи говори о окрепљењу јунака, то значи да

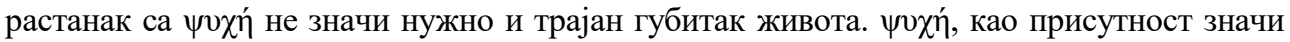
будност; након што је од ње растављен, човек престаје видети. Имати чvхи́ још код Хомера значи бити свестан, а то додатно потврђује следећи унос:

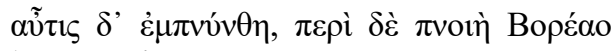

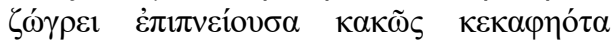
$\theta 0 \mu$ óv. $^{8}$ ал` му се поврати свест, и пиркањем борејски ветрић, стане га оживљават` кад хоћаше бедно издахнут.

Овде се појављују још макар два битна термина. Антитетика губљења и задобијања свести, из литерарних разлога обележена засебним речима, дата је као чvхй -

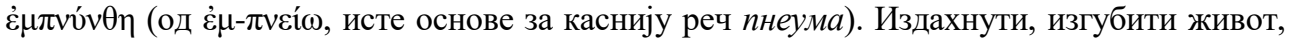
везано је за $\theta 0 \mu$ óv, реч која остаје релеванта кроз целокупну антику. Лако је уочити да све

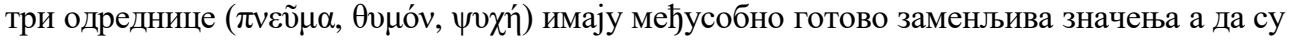
различне финесе пре одређене уметничким, говорним и другим контекстом а мање инхерентним одредницама термина.

У трећем смислу чvхи́ је центар свести, свеснога живота, личности и сопствености, центар емоција и пребивалиште срца.

Пиндар пише:

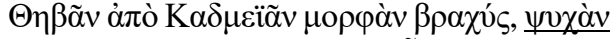

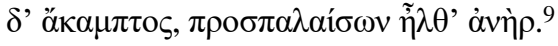

И једном они отиђоше из Тебе, Кадмусовог града, а херој, низак растом али не дрхтећег духа.

6 Homer 2015, 1.1-3.

7 Homer 2015, 5. 596.

8 Homer 2015, 5. 597-8.

9 Pindar 1990, 53. 
Овде чvхи́ нема чисто онтолошко значење већ се као принцип менталног супротставља физичком. Човек величином унутрашњости може надвладати мањкавост спољашњег. Но уколико ова два могу стајати у несразмерној напетости, како је то још и Бијант мнио, онда се једно не сме на друго сводити. Предео ұvұй је аутономан део сопства, личност, која се може развијати независно од телесних опрека.

пише:

На крају, чvұи́ има потпуно значење менталног, као када Ксенофон у Економији

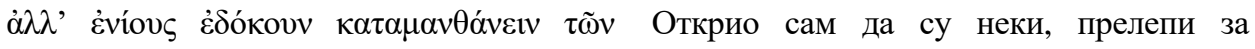

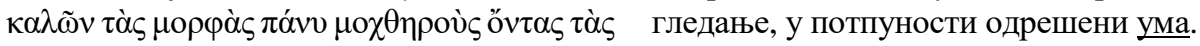
чvoxás. ${ }^{10}$

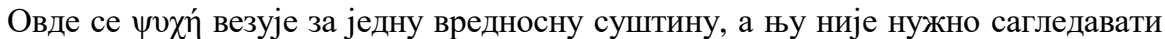
лично. Како је човек слика макро-космоса, готово свака особина која се у њему може пронаћи, још је од неког пра-почетка окупирала васељену. У вези са овим треба размотрити још једну ствар. Душа, баш зато што стоји везана за дах, дисање и живот, нарочито кроз појам $\theta 0 \mu$ óv везује се за срчани део човека. Незамисливост везивања срца са центром свести ипак није тако снажна код Хелена четвртог и петог века, те се тако јавља кардиоцентрични поглед на природу душевности. Овом гледишту примичу се Аристотел, ${ }^{11}$ Стоици и Епикурејци. Ипак, Гален је први овоме оштро противречио, те тако изнова оживео, чудновато, старију (и по свему судећи ваљанију) позицију питагороваца и Платона, складно којој се овај центар поставља унутар мозга. У De Usu Partium Corporis Humani (XVI, 3) Гален о овоме извештава:

“Јер глас који доставља мисли ума, представља најбитније од свих дела душе, и мора наравно бити створен инструментима примајућих нерава из мозга". ${ }^{12}$

Из овога је јасно да су Грци познавали оно што се данас разуме као проблем свести, са том разликом што су њему примарно прилазили кроз полисемију једнога појма потпомогнутом читавим низом другостепених изведеница које одговарају партикуларним и дистинктним својствима унутрашњости. У наставку текста разгледаћемо нека од тих својстава душе.

\section{Душа као математичко суштаство}

(a) Геометријска интерпретација душе

Постоји читав низ мислилаца који на унутрашњост гледају као на математичко суштаство. Ових суштастава, ипак, има неколико по врстама, а оне се поглавито разграничавају складно захватању геометријском, аритметичком или хармонијском

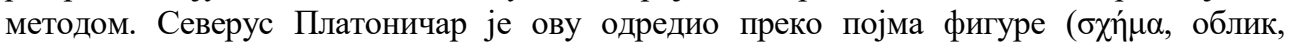
форма), ${ }^{13}$ те јој је придодао значење протежности и њене границе. У идеји ограничености

10 Ksenofan 1979, 6.16.

11 Упореди: Aristotle, 1949, 647 А 25-В 8; 665 В 0-666 A 17; Aristotle, 1937, 455 В 34-456 В 12; о томе да су сензације одређене количином крви Aristotle, 1937, 461 В 11-30, и њеним квалитетом: Aristotle, 1949, 656 В 2-6; о томе да бескрвни делови не трпе сензације, премда крв није опажајна: Aristotle, 1949, 666 А 17 18. 16; о томе да се моторичке функције контролишу срцем: Aristotle, 1949, 666 В 14-18.

12 Galen, 1538.

13Северус је са становишта историјског трагања загонетна фигура о којој мало тога знамо. Учестала

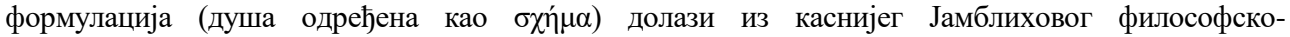
доксографског рада. Ипак, може се догодити да се овде сакрила грешка, наиме, да је на месту shema 
(nеирас) још увек се чује одјек Платона, нарочито онаквих одређења као у Менону ${ }^{14}$, но иста се ствар не може рећи поводом екстензивности. Метафизичка двојност и коегзистентни поларитети неограничености - унутрашња и спољашња бесконачност ретко су били разумевани са становишта просторне распростратости а чешће онако као однос простора и времена. Бесконачност понирања у суштаственост сопственог бића, као у Хераклитовом опиту дубине Логоса, почиње да бива очигледно у никада довршеном низу сукцесије унутарсвесних појава, а овај се схематизам да разумети кроз идеју временског поретка. Тако Северусова протежност није ограничена границама физичког тела већ се треба разумети као дијалектички однос унутрашњег и спољашњег, из чега происходи нестабилност ових категорија.

И код Спеусипа ${ }^{15}$ је душа обележена дијастатичким (протежним) моментом. Када је разматрао различите нивое, видове или начине постојања постојећег, син Платонове сестре Потоне дошао је до низа који започиње од Једног и који се даље наставља кроз број, величину, душу и предмете опажања. Сваки од ових слојева подлеже другачијим принципима те је тако овај био први који метафизичко начело हैv غ̇лі $\pi$ о $\lambda \lambda \tilde{\omega} v$ није схватио униформно. Природа, наиме, дела на тај начин, да се у различитим степенима компексности и позиционалности не понавља. Прво од постојећег, бројеви и геометријски облици, пошто Једно није постојеће већ се по снази и узвишености баш као код Платона изнад овога уздиже, рађају лепоту и доброту. Тек последњи слојеви, душау-свету, могу изродити нешто нелепо. Још је загонетније оно одређење које Спеусипу приписује Јамблих: унутрашњост, свест, душа је идеја или организациона форма свепротежности. Распростратост као услов спољашњег постојања у оваквој геометријској схеми треба да се појављује већ на другом и трећем нивоу јер је линија прва екстензивна величина ограничена бројем. Ипак, тешкоћа лежи у следећем: за разлику од њутновског савременог човека чији интуитивни зор полаже право на, готово парадоксално, апсолутистичко гледише спрам природе простора и времена као непомичних датости, Спеусип тродимензионални свет види као сужење проистекло из све даљег свођења првотне бесконачности - Једног. Прве величине онда нису одређене Еуклидовим постулатима, већ обрнуто, свет Еуклидовог простора представља геометријску рефлексију са становишта четвртог и петог слоја, душе-у-свету. Веровати да је свет геометријских и аритметичких величина онакав какав нам се показује значи за њега запасти у заблуду. Све конкретне величине и датости почивају на инваријантним облицима чија је природа везана за дубље или више метафизичке слојеве, а душа, унутрашњост позиционирана у једној тачки спољашњости, све-димензионалну распростратост Једног интерпретира у складу са сопственим законима појавности.

\section{б) Аритметичка интерпретација душе}

Друго је математичко суштаство по врсти број. Овакво одређење унутрашњости које савременом човеку делује страно и туђе своје изворе налази у питагорејству. Као број, душа је један, те се поставка може унеколико приближити; један није број

требало писати stigma (тачка). У Коментару Тимаја, Прокло, разрађујући Северусову теорију бића, каже како је овај мнио да је биће спој тачке и екстензије. Види: Proclus, 2009.

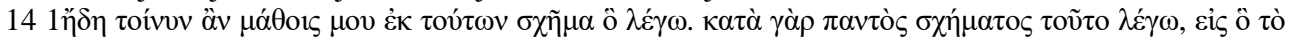

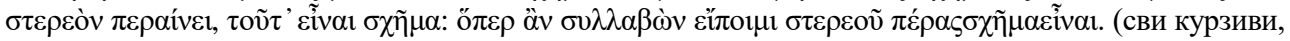
М.С.) / То је довољно да схватиш шта ја називам обликом. Ја стварно тврдим да је облик граница где се завршава тело, и то тврдим за све облике, тако да бих укратко рекао: облик је граница тела (Менон, 76а6-8).

15 Поводом Спеусипа види: Taran, 1981; поводом разраде проблема душевног у односу на ум и број, стр. 47-48; такође види фрагменте 40-60; такође: Tarrant, 1974, 130-145.; Falcon, 2000, 402-414. 
нумеричке, већ архетипске природе, те је као такав мишљен као основа бројности и стварности. У Тимају, Платоновој експозицији учења питагоровског типа, ова се идеја тематизује одређењем душе као „суштаства које је неподељено и које увек остаје исто”. ${ }^{16}$ Душа је тако нешто једно и јединствено, слично или аналогно начину на који мислимо о сопственом Ја. Као подлежеће бројности она стоји на месту монаде тетраксиса. Иста је интуиција очувана и данас. $J a$ је у човеку основна мерна јединица света јер се једино у односу на ово свет у својим слојевима може у ретроспекцији конституисати. Ипак, ово одређење не конвергира путевима савременог виђене его-свести ( $а$ одређено као садржај тога ја) што је јасно још од времена Хипасије Питагорејца ${ }^{17}$; унутрашњост је, вели он, инструмент помоћу којег Бог, стваралац света, мери. Дакле, битна унутрашњост денотирана и у мисао призвана контемплацијом идеје сопствености није удешена по мери палог човека (човека гвозденог доба или палог Адама) већ једино Бога. Овиме се ja, из перспективе јунгијанске терминологије, да обележити идејом сопства. И Ксенократ се приближава сличној линији мисли када број (јединицу) која је душа, обележава као самопокретан. ${ }^{18}$ Ово виђење треба да је додатно појашњење Аристотеловог одређења; наиме, након што је сакупио, разврстао и размотрио квалитете који су му се чинили да највише одговарају природи човековог унутрашњег бића, Стагиранин у De anima 1.2, души приписује три поглавита квалитета: кретање, знање и суштину. Анализа кретања је онда разумевана као питање енергетике душевности. Уколико се пита одакле му "снага" (могућност) да започне било какво кретање, онда човек одговара да он то ради сопственом вољом, као када вољно помера руку не би ли штогод дохватио. Стога је снага воље извесна енергија коју унутрашњост има на свом располагању. Да снага воље није исто што и снага тела, односно, да се енергетика унутрашњости не може свести на спољашњост, показује диспропорционалност ових двеју у многим великим моралним подвизима изведеним на самој граници телесног живота. Унутрашњост је онда, појашњава Ксенократ, само-покретна. Овакво одређење поседује још једну карактеристику која је од великог значаја: као само-покретна она је континуинална и без прекида, што значи да њену могућност (покрет и само-покрет) никада није потребно ни из чега призивати.

(в) Хармонијска интрпретација душе

Следеће математичко суштаство, складно методи захватања проблема јесте хармонија. У онтолошком смислу је битно на уму држати да се као хармонија душа не одређује по себи, независно од свога утицаја, већ као онто-релациона структура која у првом реду говори о њеном односу спрам тела/твари. Ово гледиште, фрагментарним упадима уприсутњује се кроз читаву старину, почевши од првих тематских разлагања природе душевности (сетимо се Симије питагоровца из Платоновог Федона ${ }^{19}$ ), па све до позног времена неоплатонизма. Порфирије (осамнаесто поглавље Sententiae ${ }^{20}$ ) природу

16 Platon 1981, 35a.

17 Види: Simplicii, 1882, 23.33; Iamblichus, 1998, 76.

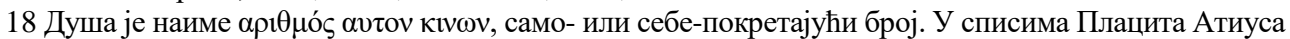
ова се формула приписује и Питагоровцима. Додуше, највећи је број текстова Ксенократових изгубљено, а међу овима и два списа: $О$ души и О Питагоровиима, тако да је могуће да је Атиусово извештавање заправо под утицајем Ксенократа. Такође поводом Ксенократа види: Granieri, 2019, 124; Valpy, A, Henry E., 2013, 272-285; Whitehead 1981, 223-244;

19 “Један би засигурно могао дати исти разлог за хармонију лире и њених жица, и рећи да је хармонија нешто невидљиво и бестелесно и веома лепо и узвишено у наштимованој лири, док су лира сама и њене жице плотна тела [...]” Платон, 1937, 85e.

20 Види: Lamberz, 1975. 
активности душе види као трансцендентну хармонију која стоји у основи свеколиког искуства. Суштинска разнородност утисака и моћи душе, пратећи овакво извођење, захтева надређени елемент који ће ове опажаје у моменту (каирос као логосна преломна тачка времена) објединити у целину. Ово је могуће стога што, дијаметрално различито Хризиповој и Зеноновој замисли, душа (као хармонија) стоји у основи чулности. Не гледа око - може се појаснити Порфиријева замисао - већ душа иманентном хармонијском уређеношћу, уприсутњеном у органу, овај користи по сопственој вољи. Занимљив је мада суд о адекватности приказа може отићи на обе стране - један фрагмент из Прокловог коментара Тимаја (2.213.8 - 215.28) који овај посвећује управо излагању Порфиријевог виђења: душа, наиме, „целину космоса испуњава хармонијом”. 21 Ово је даља концептуализација виђења према коме душа, мада се сада не сме узети у њеном индивидуалном (отцепљеном или палом) смислу, већ унапред стоји присутна у целини, баш зато што се космос одређује појмовима мере, склада, реда и броја. Порфиријево излагање, како се може закључити из хронологије, тематског и појмовног приступа, настаје инспирисан једним Плотиновим уносом насловљеним О бесмртности онога што нема тело. ${ }^{22}$ Претходно разматрање међузависне активности органа и душе, овде, на темељима аналогије Симије питагоровца, засијаће у пуноме сјају: „жице не би могле бити покренуте чак и да музичар то жели, да хармонија то не каже”. Проблем оваквог приказа показује се у бићевности музичара (инстанце воље, па стога експонента, заступника душе), који се ставља напоредо са свим другим бићима. Душа, премда суштаствена, није једно од бића (већ се у овоме може мислити доцнија Хајдегерова онтолошка разлика), не стоји као једно напоредо са другим постојећим; она се од осталог разликује на онај начин на који се средиште круга разликује од његове ивице, онда када се ивици приписује сав реалитет. Душа је мера одстојања, хармонијска изведеница која неопажено чини радијус и закривљење и тако у принципијелном смислу стоји као његова основа. „Пошто [...] у опажајном поретку постоји оно што је потпуно дељиво, тада пре опажајног поретка а некако близу њега и у њему (нагласио М. С.) постоји нека друга природа која није примарно дељива као тела”. ${ }^{3}$ Као једност „она није једно како је тело једно”. ${ }^{24}$ Душа је једност које не стоји поред, насупрот, испод или изнад многог (премда су некада ови термини згодни), она је једност суштаствено другачија од многости, једност у којој се многост као могућност рађа; она треба да је једно које се призива када се каже „свет је један” и „Бог је један”. Да је одиста тешко понудити чист језик којим би се ово исказало, говори и Плотинова употреба овог крајње неодређеног “некако”.

Ово гледиште нужним путем упућује на то да постојање није само спољашњи феномен, да оно има своју унутрашњу страну, нама, осим у случају сопствености одиста недодирљиву, унутрашњост макар у неким тачкама коегзистентну спољашности, феномен који не може бити локализован на тај начин да се у његовој појединачности не може препознати општост, те тако феномен који из крајности мења наш поглед на природу и структуру онога што називамо стварношћу.

21 Proclus, 2009, нарочито поглавље Excursus on prayer and the gods.

22 Плотин 1984, 3. 6,4.

23 Плотин 1984, 4.1,1.

24 Плотин 1984, 4.1,1. 


\section{Литература}

Aristotel (2001): De Anima. Rasprava o duši. Podgorica: Oktoih.

Aristotle (1937): Parva Naturalia. Cambridge. Harvard University Press.

Aristotle (1949): De Partibus Animalium. Cambrigde. Harvard University Press .

Galen (1538): De usu partium corporis humani libri XVII. In officina Christiani Wecheli. (у изворном стању дигитализовано у оквору Google Books пројекта)

Xenophon (1979): Xenophon Economics in Xenophon in Seven Volumes. London. Harvard University Press.

Lamberz. E. (1975): Porphyrii sententiae. Leipzig. Scriptorvm Graecorvm Et Romanorvm.

Pindar (1997): Isthmian. Cambrigde. Harvard University Press.

Platon (1981): Timaj. Београд. Mladost.

Platon (1937): Fedon ili o duši. Beograd. Zadruga Profesorskog društva.

Плотин (1984): Енеаде. Београд: Књижевне новине.

Plutarch (1928): Moralia (On Stoic Self-Contradictions and Against the Stoics on Common Conceptions). Cambridge. Cambridge University Press.

Press.

Proclus (2009): Commentary on Plato's Timaeus. Cambridge. Cambridge University

Heraklit (1981): Fragmenti. Beograd: Grafos.

Homer (2015): Ilijada. Beograd: Dereta.

Iamblichus (1998): De Communi Mathematica Scientia, Michigan, University of Michigan Press.

Kurdzialek, M. (1971): "Der Mensch als Abbild des Kosmos", Miscellanea mediaevalia, Bd. 8, Berling 1971.

Simplicii (1882): Aristotelis Physicorum libros quattuor priores/posteriores commentaria, Berlin, Commentaria in Aristotelem Graeca.

Taran, L. (1981): Speusippus of Athens. Leiden. E. J. Brill.

Tarrant, H. A. S. (1974): “Speusippus' Ontological Classification”, Phronesis, Vol. 19, No. 2.

Falcon, A. (2000): “Aristotle, Speusippus, and the Method of Division”, The Classical Quarterly, Vol. 50, No. 2.

Granieri, R. (2019): "Xenocrates and the Two-Category Scheme", De Gruyter, Apeiron.

Valpy, A, Henry E. (2013): "Extracts from some of the lost Works of Aristotle, Xenocrates, and Theophrastus", The Classical Journal, Vol. 10.

Whitehead D. (1981): "Xenocrates the Metic", Rheinisches Museum für Philologie, Neue Folge, 124. Bd., H. 3/4.

Scott, A. (1991): “Origen's Use of Xenocrates of Ephesus”, Vigiliae Christianae, Vol. 45 , No. 3 . 


\section{Mihailo Stojanović}

\section{THE CONCEPT OF THE SOUL IN ANCIENT TIMES}

In ancient philosophy, the concepts of soul, interiority, and consciousness are in their intended meaning found to be very close. The term $\psi v \chi \tilde{n}$ is an overly polysemous determinant that contains within itself a whole series of subtle semantic characteristics that seem to revolve around a single center. Many ancient thinkers think about the soul as of a mathematical being. Still, there are several of these beings categorized by species, and these species are mainly distinguished according to the geometric, arithmetic, or harmonic method of understanding. 